\title{
The Moderating Influence of HR Operational Autonomy on the Entrepreneurial Orientation-Performance Link in Franchise Systems
}

\begin{abstract}
This study investigates the concept of HR Operational Autonomy, i.e., the freedom a franchisor offers to franchisees throughout the system with regards to their creation of HR practices. It is shown to have a significant positive moderating effect on the EO-performance link among UK franchise systems, explaining over 20 percent of the variance in performance outcomes. Implications and future research directions are discussed.
\end{abstract}

Keywords:

Human Resources, HR, Operational Autonomy, Entrepreneurial Orientation, Performance 


\section{The Moderating Influence of HR Operational Autonomy on the Entrepreneurial Orientation-Performance Link in Franchise Systems}

\section{INTRODUCTION}

Entrepreneurial orientation (EO) has received acclaim as a key concept for firm success (Wang 2008), with research on the topic ranging from SMEs (Avlonitis and Salavou 2007; Keh, Nguyen and Ng 2007; Moreno and Casillas 2008) to spin-offs (Walter, Auer and Ritter 2006) and technology start-ups (Lee, Lee and Pennings 2001). However, few studies have investigated EO in franchised firms (e.g. Falbe, Dandridge and Kumar 1998), despite the fact that franchising has been recognized as a distinct type of entrepreneurial partnership (Davies, Lassar, Manolis, Prince and Winsor 2011). This study extends recent research by Dada and Watson (2013) in which EO was found to have a positive and significant influence on the performance of franchise systems. This research investigates the moderating effect of operational autonomy in the area of human resource policies ("HR Operational Autonomy”) on the EO-performance relationship in franchise systems.

A common assumption about franchised businesses is that virtually every aspect of such systems is regulated via contract in order to ensure systemwide standardization. Anecdotal evidence, however, suggests that specific areas of franchise systems may remain almost entirely unregulated by the franchisor, hence, leaving substantial freedoms for franchisees. One of these areas is the management of human resources. HR management has been identified previously as a critical driver of success in the service and retail industries (McLean 2006; Miller 2006) in which business format franchising is a prevalent business model (Combs and Ketchen 2003; Welsh, Alon and Falbe 2006). Recent research (Brand and Croonen 2010; Castrogiovanni and Kidwell 2010) has noted the particular salience of HR policies in a franchising context, facilitating both the standardization of rules across units as well as adaptation to local labor conditions and markets. Often, responsibility for the 
management of HR is delegated without much regulation to individual franchisees (Brand and Croonen 2010). This may entail hiring procedures, incentives, as well as advancement and promotion. Being able to attract and retain effective employees has been shown to enhance performance in non-franchise contexts (e.g., Youndt, Snell, Dean and Lepak 1996), and may contribute to the success of individual franchisees' operations. In turn, such "pockets" of freedom which foster entrepreneurial activities by franchisees might also enhance the performance of the entire franchise system. Consequently, allowing franchisees such freedoms strategically may offer a distinct competitive advantage to franchisors who capitalize on the benefits of such arrangements. Franchise chains may choose to create specific areas of operational autonomy within their systems, i.e., refraining from regulating operational areas that may contribute more positively to their success if left alone rather than being “stifled” by system rules.

In the subsequent section the relevant background literature on franchising, the EOperformance link and HR Operational Autonomy is reviewed briefly, and a hypothesis is developed. Findings from a survey study of franchisors in the United Kingdom are reported. The limitations as well as managerial and research implications conclude the paper.

\section{LITERATURE REVIEW and HYPOTHESIS DEVELOPMENT}

\section{Franchising}

Franchising ${ }^{1}$ is a popular business model which allows a firm’s geographically distant customer base to be served through a network of local units (Cox and Mason 2007). The franchisee provides the capital for franchise units, whereas the decision-making power over many issues important to the success of outlets remains with the franchisor (Elango and Fried

\footnotetext{
1 This paper focuses on business format franchising, which "occurs when a firm (the franchisor) sells the right to use its trade name, operating systems, and product specifications to another firm (the franchisee)” (Castrogiovanni, Combs and Justis 2006, p.27-28).
} 
1997). As the franchisor’s prime concern lies in protecting brand equity (Stanworth 1991), standardization and uniformity constitute the foundations of franchising (Cox and Mason 2007). However, free-riding franchisees may behave in an opportunistic fashion by intentionally neglecting the franchisor's goals and deviating from the franchisor's established system to pursue their own entrepreneurial interests (Baucus, Baucus and Human 1996; Gassenheimer, Baucus and Baucus 1996).

The franchise literature offers many examples that franchisees are critical sources of novel ideas (Bradach 1998; Bürkle and Posselt 2008; Clarkin and Rosa 2005; Cox and Mason 2007; Darr, Argote and Epple 1995; Stanworth, Healeas, Purdy, Watson and Stanworth 2003). Kaufmann and Eroglu (1999) have shown that it is often franchisees who create new products, modify existing ones, and come up with solutions to system problems in their efforts to adapt to local market conditions. Moreover, franchisees operate in diverse environments characterized by variations in income, consumer wants, and degrees of competition (Cox and Mason 2007). These may necessitate entrepreneurial behaviors in franchised outlets in order to adapt to local markets. However, considerable disagreement exists as to how much franchisors really want their franchisees to be entrepreneurial (cf. Grünhagen and Mittelstaedt 2005). Franchisors are often said to prefer managers, rather than entrepreneurs, as franchisees in order to protect their business systems from unwanted change (Birkeland 2002; Cox and Mason 2007; Falbe et al. 1998). Despite this, it would seem that developing system-wide strategies to foster entrepreneurship may add value to the system. A recent study by Dada and Watson (2013) found that EO had a positive impact on system performance. Given recent suggestions (Brand and Croonen 2010; Castrogiovanni and Kidwell 2010) that HR practices are one opportunity by which franchise systems appear to not only tolerate but encourage adaptability by local franchisees, this study seeks to add to the extant franchise research linking EO, HR practices and franchise system performance. 


\section{Entrepreneurial Orientation}

Entrepreneurial orientation (EO) is one of the most studied and widely accepted firmlevel constructs in the entrepreneurship literature (George and Marino 2011; Wales, Monsen and McKelvie 2011). EO is used to capture the degree to which the firm’s posture may be characterized as entrepreneurial versus conservative (Morris, Schindehutte and LaForge 2002), and finds its origin in the research of Miller (1983, p. 770) who noted that an entrepreneurial firm is one that "engages in product market innovation, undertakes somewhat risky ventures and is first to come up with 'proactive' innovations, beating competitors to the punch”. Contained in Miller's definition are three underlying dimensions of EO: innovativeness, proactiveness, and risk taking. As the combined level of the three dimensions increase in the firm, so does its overall level of EO (Kreiser 2011). Research to date assumes that EO is a behavioral orientation or posture that may apply to any type of organization (Morris et al. 2002).

Despite the increasing number of studies on EO, there has been a lack of consistency regarding the conceptual domain of the construct (George and Marino 2011). As Covin and Lumpkin (2011) explain, the EO construct has been conceptualized in two main ways: (1) as a unidimensional or composite construct as generally associated with the studies of Miller (1983) and Covin and Slevin (1989), or (2) as a multidimensional construct as generally associated with the study of Lumpkin and Dess (1996). Based on the unidimensional view of $\mathrm{EO}$, the latent construct is understood to exist only to the extent that risk taking, innovativeness, and proactiveness are simultaneously manifested by the firm (Covin and Lumpkin 2011). In other words, statistically, EO is the common or shared variance among risk taking, innovativeness, and proactiveness (Covin and Lumpkin 2011). Based on the multidimensional view of EO, the latent construct exists as a set of independent dimensions, namely risk taking, innovativeness, proactiveness, competitive aggressiveness, and autonomy 
(Covin and Lumpkin 2011). In other words, a competing view is that these five separate dimensions make up the construct of EO. Covin and Lumpkin (2011) stressed further that there has been a tendency for researchers to compare these two conceptualizations of EO in order to determine which is a more theoretically valid approach. However, there appears to be strongest consensus amongst academics (Wiklund and Shepherd 2005) around the foregoing three dimensions originally posited by Miller (1983), with most EO studies centering on these three dimensions (Miller 2011; Morris et al. 2002).

As very little is known on EO within the franchising context, the approach chosen in this study mirrors the unidimensional conceptualization of EO used by Dada and Watson (2013) to establish empirically the positive and significant impact of EO on franchise system performance. In line with their conceptualization, the focus of this study is also on innovativeness, proactiveness and risk-taking as the underlying dimensions of EO.

\section{EO and Performance}

Past studies have used different performance measures to investigate the link between EO and firm performance, including financial measures like profit growth, sales growth, and market share growth (De Clercq, Dimov and Thongpapanl 2010). While several studies have used objective measures such as information from the firms' annual accounts (Moreno and Casillas 2008) or information collected directly from the organizations’ accounting offices (Walter et al. 2006), other studies have utilized subjective indicators, such as perceptions of the firm's performance relative to its main competitors during a particular time period, e.g., the past three or five years (De Clercq et al. 2010; Tang, Tang, Marino, Zhang and Li 2008; Wang 2008). Although perceptual data have limitations regarding enhanced measurement error and potential mono-method bias (Keh et al. 2007), previous research has also found that subjective performance measures may reflect objective measures correctly (Lumpkin and 
Dess 2001). Further, respondents frequently refuse to provide (objective) figures related to company performance (Walter et al. 2006), hence necessitating the use of alternative subjective measures.

Other studies have also used non-financial performance measures. For example, Keh et al. (2007) used perceptual data to show non-financial performance, employing items related to realizing start-up goals, offering secure jobs, and satisfaction with firm performance. Walter et al. (2006) also used perceptual measures in their study of the influence of network capability and EO on organizational performance. The study's nonfinancial measures involved perceived customer relationship quality, realized competitive advantages, and ensuring long-term survival.

As mentioned earlier, however, in the franchise realm franchisee standardization and uniformity, as opposed to franchisee entrepreneurial behavior ${ }^{2}$, are commonly believed to be central for franchise system performance. Prior studies (e.g. Davies et al. 2011) have stressed the franchisor's attempts to enforce franchisee compliance with operational standards and corporate rules. Hence, entrepreneurial behavior, such as undertaking innovations, seems to be the right of the franchisor and he/she will desire to persuade all franchisees to adopt new products, services, and marketing activities in the interest of standardization. Further, while there is a body of literature (e.g. Bradach 1997; Falbe et al. 1998; Gillis and Combs 2009; Kaufmann and Eroglu 1999) that emphasizes the role of franchisees in helping franchisors adapt and be innovative, and their ability to create value through the generation of such innovations (Gillis and Combs 2009), allowing independent franchisee innovations to take place at different territorial areas may be detrimental to the franchise system. This view may

\footnotetext{
${ }^{2}$ It should be noted that a recent study of thought leaders in entrepreneurship in Entrepreneurship Theory \& Practice (Ketchen, Short and Combs 2011) revealed that perceptions were split on the question as to whether franchisees are entrepreneurs, although the majority considered franchisors to be entrepreneurs.
} 
be attributed to the variations that innovative franchisees might introduce into the system which could cause dilutions to the standardized procedures and format of the franchisor and lead to inconsistencies in brand image. However, recent empirical evidence (Dada and Watson 2013) suggests that system EO does have a positive and significant impact on franchise network performance.

\section{The Moderator Role of HR Operational Autonomy}

There are two main streams of research that evaluate the relationship between human resource practices and performance. The first is the universalistic or "best practices" approach. Those utilizing this approach point to repeated supportive findings to demonstrate that some HR practices, such as recruiting intensity, internal career opportunities, performance appraisal, formal training systems, profit sharing, and incentive compensation are so well-documented in multiple contexts as to suggest that there is a universality of them (Delaney, Lewin and Ichniowski 1989; Delery and Doty 1996; Huselid 1995; MacDuffie 1995). This suggests that these best practices can be adopted by managers and organizations and expect favorable results.

The second approach researchers have taken is the contextual or contingency basis that argues HR practices need to be selected by firms according to their particular business needs (Becker and Huselid 1998; Delery 1998) or in line with their competitive strategy (Delery and Doty 1996; Gomez-Mejia and Balkin 1992). In examining compensation systems alone, Gomez-Mejia (1992) suggests a continuum of practices between the algorithmic and experiential approach. Algorithmic patterns of pay focuses on "predetermined, standardized, repetitive procedures” (p. 382) with strong emphasis in distributing pay and rewards based on hierarchical position, seniority and a preference for behavioral monitoring rather than endresults. Experiential patterns of pay are adaptive means to respond to unique competitive 
environments where there is risk-sharing between the firm and its employees, performancebased rewards, and pay determined by personal skills and attributes. While there are those who advocate strongly for the use of piece-rate incentives, others have illustrated adverse events in some contexts when employees become focused on their individual goals, resulting in conflict amongst employees related to individual “counts,” lower customer service ratings, and ethical violations (Latham 2004).

There is also an argument that the "best practices" and "best fit” approaches to HR practices can be complementary (Youndt et al. 1996). Both individual HR practices and internally consistent HR systems are demonstrably linked directly to firm performance (Youndt et al. 1996). In franchising, this could be franchisor-mandated training programs for equipment and preparation of products and services (Brand and Croonen 2010). But as franchise researchers have indicated, franchisees have considerable investment at risk (Castrogiovanni and Justis 1998) that make them more motivated to create policies and implement practices that will benefit their individual competitive environment (Castrogiovanni and Kidwell 2010). Thus, it is suggested that franchisors are maximizing the opportunity for performance by instituting a combination of "best practices" within a franchise system, as well as allowing "best fit” opportunities for franchisees to define specific HR practices that they want in accordance with local conditions or management approach (contingency).

More recently, entrepreneurship researchers have begun to focus their attention on human resource management practices as an important influence to improving performance (Brand and Croonen 2010; Castrogiovanni and Kidwell 2010). Indeed, Pfeffer (1995) argues that in the management of organizations, HR management is the only area where competitive advantage is created. In HR research, isolating the entrepreneurship context is not evident in published work, though it seems likely that studies have used entrepreneurial and/or 
franchised operations in their work and as field sites. A weaker centralized HR function from the franchisor allows for an entrepreneurial climate that encourages each business unit to be innovative in their development of HR practices.

Windsperger (2004) uses Property Rights Theory to explicate that the allocation of decision rights in franchise systems depends on the distribution of intangible know-how between franchisor and franchisee. Specifically, he outlines that franchisees' intangible assets include HR management know-how (Windsperger 2004, p.1363). Hence, in franchise systems HR know-how represents a category of expertise that dictates the decentralization of its decision rights to franchisees, so that the decentralization of HR management is a systemlevel decision which then relegates autonomy over HR operational decisions to franchisees.

Indeed, franchisors may have expectations and design their franchisee relationships so that franchisee HR practices are of their own making (Brand and Croonen 2010). Legal responsibilities are also likely factors influencing the franchisor decision to allow franchisee autonomy in HR practices (Brand and Croonen 2010). As a corporation moves into higher levels of diversification, there is a shift from experiential to more algorithmic practices (Balkin and Gomez-Mejia 1990). In the franchising context, where franchisees find the need to adapt to local competitive human resource practices and are less likely to be concerned with large, diversified corporate management, experiential HR practices are more likely to be found. Further, where the franchisee is assuming much of the risk of profit and loss and their own personal involvement in the success of the franchise operation, allowing flexibility in staffing and pay practices provides the franchisee the opportunity to adjust profit margins based on their own operational management. Thus, the investment-oriented franchisee that continues full-time employment in another profession may give up greater profit-margins and instead design an incentive reward structure and hire a professional, experienced manager for day-to-day operational control. On the other hand, corporate-owned franchise operations are 
more likely to develop algorithmic systems that provide consistent and fairly predictable costs across multiple units in the franchise system.

Given the evidence from recent research in this domain, it is likely that franchise systems vary in the opportunity franchisors allow for operational autonomy in HR practices, i.e., the freedom a franchisor offers to franchisees throughout the system with regards to their creation of HR practices. This "HR Operational Autonomy” which franchisors provide to their franchisees is hypothesized to moderate the relationship between a system-wide entrepreneurial orientation and franchise system performance.

H: $\quad$ HR Operational Autonomy has a positive moderating influence on the relationship between EO and the performance outcomes of franchise systems.

\section{METHODOLOGY}

\section{Sample and Data Collection}

To test the hypothesis, a mail survey was used to collect data from UK-based franchisors. The investigation was part of a larger study investigating the entrepreneurial attitudes in franchise systems. The survey questionnaire was first piloted with a small number of franchisors. After this, the final version was mailed to all the franchisors operating in the U.K., using the franchise listings provided in a major franchise publication, the British Franchise Directory \& Guide. According to the latest source available, around 809 franchisors are actively operating in the U.K. (NatWest/British Franchise Association Survey 2008). The survey pack also included a postage-paid reply envelope and a cover letter to the franchisor. Franchisors were specifically involved as key informants (Phillips 1981) because they are expected to be familiar with the research issues and the information sought (Avlonitis and Salavou 2007; Simsek, Veiga and Lubatkin 2007) and could therefore respond accurately (Zahra and Covin 1995). From the original mailing, 72 completed questionnaires were received, 25 from the first round of reminders, and none from the second round of 
reminders, resulting in a total number of completed questionnaires of 97 . Two questionnaires were excluded because they were insufficiently completed. Therefore, our final sample consisted of 95 franchise systems, an overall response rate of 11.74 percent of the total number of UK-based franchise systems. Considering this study’s requirement for top executives’ direct involvement (cf., Lee et al. 2001), the response rate was considered adequate and consistent with the 10-12 percent response rate typical for mailed surveys to top executives (Hambrick, Geletkanycz, and Fredrickson 1993; Simsek, Heavey, and Veiga 2010; Simsek et al. 2007). Also, a response rate of less than 10 percent has been reported frequently in prior franchising studies (e.g., Grace and Weaven 2011; Jambulingam and Nevin 1999). The characteristics of the sample are presented in Table 1 . The sample included both well established and young franchise systems and was considered representative of the franchise sector in the U.K.

\section{Insert Table 1 Here}

Two important concerns associated with survey methodology are nonresponse bias and common method variance (Li, Zhao, Tan and Liu 2008). To examine the possibility of nonresponse bias in this study, respondents were separated into two groups according to when they asnwered the survey: (1) 'early respondents' were those who responded to the original mailing, and (2) 'late respondents' were those who responded after the original mailing, in other words, they responded to the first round of reminders. It was assumed that 'late respondents’ were similar to nonrespondents (Armstrong and Overton 1977). T-test comparisons of the two groups on the key constructs did not reveal statistically significant differences. Thus, no significant evidence of nonresponse bias was found in this study.

A common method variance problem may result from using the same respondents in the same survey (Li et al. 2008) and may represent a threat to the psychometric properties of 
questionnaires (Tepper and Tepper 1993). This study used single respondents, hence introducing the possibility of a common method bias (Simsek et al. 2007). In order to address concerns relating to common method biases, in this study response anonymity and confidentiality were guaranteed to respondents, as suggested by Podsakoff, MacKenzie, Lee, and Podsakoff (2003) and Wang (2008). In addition, the Harman one-factor test (Podsakoff et al. 2003; Podsakoff and Organ 1986) was utilized. Accordingly, the items from all constructs in this research were included in an exploratory factor analysis (EFA). No single factor resulted from the factor analysis and no one factor accounted for most of the variance, thus indicating that common method variance was not a likely problem in the data (Rhee, Park and Lee 2009).

\section{Variables and Measures}

Measures were adapted from prior studies and were re-worded to fit the franchising context in general and/or to specifically fit the franchisor perspective. Most measures for the constructs were developed from prior studies and were re-worded slightly to fit the franchising context. The modifications made to the measures were very minor and they relate mostly to interchanging general words like firm/organization with words specific to the franchising context e.g. franchise system, franchisees, franchised outlet etc. (as shown in Table 3). The measures for the constructs are discussed under the respective variables below, with reference made to those prior studies from which the measures were developed.

Summated scale scores were created for each construct (Hughes and Morgan 2007). Tests for reliability were conducted using Cronbach’s alpha. The values for all scales were above 0.70 , the recommended minimum acceptable standard (Nunnally 1978, p. 245-246). All item-to-total correlations in this study were reasonably high, in the expected direction, and statistically significant at the 0.01 level (2-tailed) (Hughes and Morgan 2007). Thus, 
satisfactory evidence to suggest that the data were appropriate for analysis was found. Table 2 shows the correlation matrix.

\section{Insert Table 2 Here}

Dependent Variable. In accordance with Wiklund and Shepherd (2005) this study treated performance as a multidimensional construct. Thus, both financial and non-financial measures of performance outcomes were used according to the perception of the respondent, using the pooled performance scale adapted from Keh et al. (2007). Respondents were specifically prompted to think of and refer to the franchised units of their system when responding to the questions. Financial performance was measured by asking respondents to compare their franchise system to that of their competitors in the last 3 years with regards to sales growth, profitability, market share, and overall financial performance. A 5-point Likert scale, ranging from 1: Much weaker to 5: Much better, was employed. The non-financial performance items related to provision of secure jobs for franchisees, satisfaction with franchisees’ overall performance, and realization of franchising goals. A 5-point Likert scale, ranging from 1: Strongly disagree to 5: Strongly agree, was used to assess the extent of agreement with each of the items in the last 3 years. The overall Cronbach's alpha value of the performance scale was 0.82 (see Table 3).

Independent Variable. The independent variable, entrepreneurial orientation (EO), was measured by three dimensions: innovativeness, proactiveness and risk-taking (Lee et al. 2001; Wiklund, Patzelt and Shepherd 2009). In a franchise context, system EO is realized through the entrepreneurial actions of franchisees and a franchisor receptive to such initiatives. Thus, franchisors were asked about the activities of their franchisees. The 
measures for the three dimensions of EO were adapted from Keh et al. (2007), with the original measures stemming from Miller and Friesen (1982b) and Covin and Slevin (1989). A 5-point Likert scale, ranging from 1: Strongly disagree to 5: Strongly agree was used. Cronbach’s alpha of the EO scale was 0.76 (see Table 3).

Moderator Variable. The moderator variable, HR Operational Autonomy, was measured by focusing on one aspect of franchisee operations, autonomy in human resource policies. An original scale of 16 items was created based on "best practices" as identified by previous research (e.g., Youndt et al. 1996). After the EFA was conducted, a five-item scale with a Cronbach’s alpha of 0.83 (see Table 3) emerged as the final scale on which respondents were asked to assess the extent to which the following items are descriptive of their franchise systems on a 5-point Likert scale, ranging from 1: Not at all descriptive to 5: Very descriptive: (1) franchisees are free to establish their own standards for employee evaluation; (2) franchisees determine their own safety and security policies; (3) franchisees can decide how often they perform employee performance appraisals; (4) franchisees set their own internal compensation and pay standards; and (5) franchisees have control over negotiations and relationships with unions.

Control Variables. A set of control variables was included to ensure that the models were appropriately specified and permitted alternative explanations for variations in performance (De Clercq et al. 2010). Firms of different age and size could reflect different environmental and organizational characteristics. Therefore, age and size of the franchise systems were used as controls. An overview of all scale items can be found in Table 3. 


\section{ANALYSES AND RESULTS}

At the start of the data analysis, multicollinearity between the constructs was explored. The maximum variance inflation factor was 1.49 and the maximum condition index was 8.23. Therefore, no multicollinearity problems were discovered (Walter et al. 2006).

The hypothesis was tested using moderated regression analysis. The first test (Model 1) involved regressing the dependent variable, performance, on the control variables and EO, hence, representing the "base" model. To test the hypothesized moderating influence of HR Operational Autonomy on the relationship between EO and performance, Model 2 involved regressing the dependent variable (performance) on the control variables, EO, HR Operational Autonomy, and an interaction term generated by multiplying EO and operational autonomy. To alleviate the potential threat of multicollinearity, the variables required for the interaction term were mean-centered before creating the interaction term (Wiklund and Shepherd 2005).

The results, presented in Table 4, show that Model 1 was significant $(\mathrm{p}<0.01)$ and explained approximately $17 \%$ of the variance in performance, using the pooled performance scale adapted from Keh et al. (2007). EO was significant and positively related $(\beta=0.275$; $\mathrm{p}<0.05$ ) to performance, thus supporting the basic main effect established elsewhere (Dada and Watson 2013). Testing the hypothesis developed for this study, Model 2 was significant and explained $23 \%$ of the variance in performance. The interaction term EO*operational autonomy was positive and significant $(\beta=0.220 ; \mathrm{p}<0.05)$. Hence the hypothesis was supported. Further, Model 2 also explains significant additional variance in performance $\left(\Delta \mathrm{R}^{2}\right.$ $=0.064 ; \mathrm{p}<0.01)$ as compared to the base Model 1 . 


\section{DISCUSSION OF FINDINGS}

For franchise systems, a key challenge is to engage in innovation while preserving the level of standardization required for the system (Kaufmann and Eroglu 1999). To customers, the more obvious innovations involve a change in the product, packaging, or distribution of a service. However, from a franchising perspective, product and service innovations are often core to the brand identity that is being preserved in the franchise model. Thus, innovations that directly involve products or services are more likely to be influenced by the franchisor, whereas non-product or non-service business process innovations lend themselves more to franchisee influence since they are less threatening to the core business format. In this research, the focus has been on franchisors' perceived allowance for franchisees to innovate and customize what is likely to be the most significant non-standardized aspect of the franchise operation: human resource management (Pfeffer 1995). Human resource management is an operational area in which franchisees can be allowed some autonomy (Brand and Croonen, 2010), without threatening the core business format.

The results in this study suggest that flexible HR policies moderate the impact of Entrepreneurial Orientation (EO) on system performance, such that when franchisees are given greater autonomy in HR policies, EO has a stronger positive impact on system performance. In simpler terms, a very important takeaway is that franchise systems that consider themselves as being entrepreneurially oriented or encouraging the "entrepreneurial" franchisee now have evidence to support a very important mechanism to channel that entrepreneurial energy: innovate human resource practices at your franchisee level. The results support Brand and Croonen’s (2010) contention that local adaptation in HR practices by franchisees is beneficial to the franchise system. While many of the surveyed franchisors appear to have recognized the potential benefits of delegating responsibility for setting pay and rewards to their franchisees (the mean score was 3.99), overall HR flexibility achieved a 
mean score of 3.14, suggesting that franchisors have perhaps not fully leveraged their franchisees’ local market knowledge and skills in this respect.

For practitioners, our findings have practical implications that can be implemented to fit the franchise context. In keeping with our earlier discussion of HR theory, we advocate for the complementary approach in which the franchisor identifies a number of "best practices" for their franchise system, but then allows for "best fit" HR practices that the franchisee can engage to fit their local labor market and local economic conditions. This may include compensation and benefit packages, training needs, the composition of full-time to part-time staff, implementation of reward systems, and discipline expectations.

Stronger performance resulting from greater HR Operational Autonomy may also turn into a competitive franchisee recruiting toll. Prospective franchisees with a strong HR background may be particularly attracted to a system that offers flexibility regarding its HR practices, thus allowing the franchisor to broaden the system's traditional recruiting pool. Davies et al. (2011, p. 1) highlight the challenge that franchisors face in balancing “franchisee aspirations for entrepreneurial autonomy with the franchisor's efforts to enforce compliance”. Providing greater autonomy to franchisees in HR policy could help achieve this balance.

In franchising, learning and sharing occurs not only through franchisors' sharing of benchmark practices through newsletters and bulletins (see Grünhagen, DiPietro, Stassen and Frazer 2008), but also through franchisees' membership in various associations at the regional and national level. Thus, franchisee associations within franchise systems should be encouraged to provide outlets (e.g., newsletters, conference sessions, communications between franchisees) for sharing of new practices among “peers” (Lawrence and Kaufmann 2011) about "best fit” practices that are being used by franchisees in managing their employees and HR practices. 
Clearly, though, innovations driven by franchisees and the autonomy afforded to them have to be aligned with and reinforce the overall core business format across the system to that the equity of the brand is not jeopardized. However, the opportunity for greater autonomy is likely to lead to more motivated and satisfied franchisees (Brand and Croonen 2010), and positively impact the franchisor-franchisee relationship (Dada and Watson 2012). Given variations in local labor markets, enabling franchisees to adapt their HR practices to fit the local environment should enhance positive performance outcomes.

In the context of franchising research, we have extended and supported recent findings (Brand and Croonen 2010, Castrogiovanni and Kidwell 2010) that HR systems and choices of HR practices play an important contributing role in franchise success. For researchers in the field of HR, we would encourage additional analysis and study of impact of specific HR practices and conditions that lead to higher impact performance. For our study, in an exploratory approach to identify that HR was important to performance in the context of franchise systems, we considered multiple HR activities together as one bundle. However, research in HR points to the significance of applicant skills testing and employee skills training (Huselid 1995), for example, as potentially more critical to performance measures than other HR activities. It appears likely that franchise operations relying on service provision would see a greater impact of employee training on performance than those of a product nature where there may be a lesser need for employees to improvise to address customer needs. Being able to develop theoretical linkages between specific HR practices, their impact on motivation, satisfaction, justice, and/or self-efficacy, and different types of organizational performance would provide much more substantial direction and implications for the future of our findings (Guest 1997). 


\section{LIMITATIONS AND RECOMMENDATIONS FOR FUTURE RESEARCH}

As with all research, this study is not free of limitations. A first potential limitation pertains to the sample. As it was a cross-sectional sample, i.e., it was drawn from several industries, this might increase generalizability but eliminate significant differences. However, the limited sample base for U.K.-based franchisors meant that a single sector survey would be unlikely to generate sufficient responses. Also, similar to Keh et al. (2007), an industry effect could not be controlled for due to the small numbers in most of the industry sectors in this research. An extension of this study for future research (in line with Keh et al.’s (2007) suggestion) would be to collect larger samples, especially from larger franchise markets such as the US, and capture industry differences.

This paper, in exploring the moderating effect of HR policies, provides some useful insights into those areas of the franchise business system where local adaptation by franchisees can have positive performance outcomes. Previous work on franchising has highlighted the difficulties in balancing the desire for system uniformity whilst allowing for local adaptations (Kaufmann and Eroglu 1999), yet, as Gillis and Combs (2009, p. 555) argue, “franchisees’ local knowledge and profit motive place them in a strong position to create value by increasing adaptation and generating innovations.” Kaufmann and Eroglu (1999) suggest that franchisors must be careful to standardize, what they term 'core' elements of their format, but that peripheral elements can be adapted. In this context, Terry and DiLernia (2011) introduced the distinction between "front of house” franchise elements (comprising the brand, image, standardized quality, appearance of the premises) and "back of house” elements (comprising the system underlying the external manifestation of the chain, including training, technology, and the operations manual). Arguably, HR policies could be seen as a peripheral facilitator or "back of house" element to the core franchise concept, thus perhaps it is of little surprise that adaptations here have a positive impact. However, as 
Kaufmann and Eroglu (1999) acknowledge, it is difficult to determine what areas of the franchise concept can be considered core, and which peripheral. Thus, franchisors will need to consider carefully how to ensure that uniformity is maintained of core elements of the brand (where any adaptations should be systemwide: Bradach 1998), while enabling local adaptations of peripheral elements.

Future research also needs to investigate performance under conditions of HR operational autonomy at the franchisee level, to complement this study's findings of positive impact at the franchise system level. As HR Operational Autonomy was measured in this study in terms of the franchisor's perceptions of autonomy created at the franchisee level, much variation in actual perception across franchisees may have been obscured. Analysis at this level could also enable contrasts to be made between company-owned and franchised units within systems. In this study, most outlets across all systems were franchised (61\%). Future researchers may consider the differences between company-owned franchise operations in terms of HR Operational Autonomy that are likely to be more algorithmic in contrast with franchisee units that are likely to be more experiential in nature, as well as seek out clarification on the complementary approach between these two alternatives. Algorithmic HR policies emerge as a function of standardization (as opposed to customization) efforts and can be expected to be more prevalent among company-owned (as opposed to franchised) units. Not much evidence exists yet to answer the question of what context (business size, number of employees, length of franchise experience by the franchisor and franchisee for example) or the most appropriate balance between the algorithmic and experiential approach. This appears to be a fruitful research agenda to aid franchisors: how much autonomy in HR practices should franchisees be given, and in what specific areas of HR practices? Is there a targeted percentage of autonomy that yields the most favorable relationship with the 
franchisee or are there certain aspects of HR practices that the franchisor could control without detrimental impact to the franchisee or franchise system?

Another interesting future research direction may entail an examination into multiunit franchisee operations. While this study's sample in the U.K. did not include many multiunit franchisees, i.e., area development franchisees and/or sequential operators (Grünhagen and Mittelstaedt 2005), such franchisees of multi-unit operations may have to decide between a more algorithmic and standardized HR approach to their "mini-chains" on one side, and a more customized and experiential approach on the other hand.

In addition, research exploring the effect of allowing franchisee autonomy in other component areas of the franchise concept, such as advertising, site selection or local market research, and their impact on system performance could be invaluable in this respect, enabling franchisors to identify more easily those areas of the business where standardization and uniformity are critical, and those where franchisee autonomy could benefit the system. Finally, franchisee autonomy may occur in some systems as an "accidental oversight”, while other systems may, in fact, have created such "pockets” of autonomy with strategic intent to allow franchisees to utilize their local expertise and creativity in order to bolster unit, and ultimately, system performance. Hence, investigations into franchisors’ strategic decisions regarding operational autonomy left to franchisees are needed to advance this new stream of research. 


\section{REFERENCES}

Armstrong, J. S. \& Overton, T. S. (1977). Estimating non-response bias in mail surveys. Journal of Marketing Research, 14, 396-402.

Avlonitis, G. J. \& Salavou, H. E. (2007). Entrepreneurial orientation of SMEs, product innovativeness, and performance. Journal of Business Research, 60, 566575.

Balkin, D. B. \& Gomez-Mejia, L.R. (1990). Matching compensation and organizational strategies. Strategic Management Journal, 11, 153-169.

Baucus, D.A., Baucus, M. S. \& Human, S.E. (1996). Consensus in franchise organizations: A cooperative arrangement among entrepreneurs. Journal of Business Venturing, 11(5), 359-378.

Becker, B. E. \& Huselid, M. A. (1998). High performance work systems and firm performance: A synthesis of research and managerial implications. Research in Personnel and Human Resource Management, 16, 53-101.

Birkeland, P. M. (2002). Franchising Dreams: The Lure of Entrepreneurship in America. Chicago, IL: The University of Chicago.

Bradach, J. L. (1997). Using the plural form in the management of restaurant chains. Administrative Science Quarterly, 42, 276-303.

Bradach, J. L. (1998). Franchise Organizations. Boston, Massachusetts: Harvard Business School Press.

Brand, M. J. \& Croonen, E. P. M. (2010). Franchised and small, the most beautiful of all: HRM and performance in plural systems. Journal of Small Business Management, 48(4), 605-626.

Bürkle, T. \& Posselt, T. (2008). Franchising as a plural system: A risk-based explanation. Journal of Retailing, 84(1), 39-47. 
Castrogiovanni, G. J., Combs, J.G. \& Justis, R. (2006). Resource scarcity and agency theory predictions concerning the continued use of franchising in multi-outlet networks. Journal of Small Business Management, 44(1), 27-44.

Castrogiovanni, G. J. \& Justis, R. (1998). Franchising configurations and transitions. Journal of Consumer Marketing, 15, 170-190.

Castrogiovanni, G. J. \& Kidwell, R. E. (2010). Human resource management practices affecting unit managers in franchise networks. Human Resource Management, 49(2), 225-239.

Clarkin, J. E. \& Rosa, P. J. (2005). Entrepreneurial teams within franchise firms. International Small Business Journal, 23(3), 303-334.

Combs, J. G. \& Ketchen, D. J. (2003). Why do firms use franchising as an entrepreneurial strategy?: A meta-analysis. Journal of Management, 29(3), 443-465.

Covin, J.G. \& Lumpkin, G.T. (2011). Entrepreneurial orientation theory and research: Reflections on a needed construct. Entrepreneurship: Theory and Practice, 35(5), 855-872.

Covin, J. G. \& Slevin, D. P. (1989). Strategic management of small firms in hostile and benign environments. Strategic Management Journal, 10, 75-87.

Cox, J. \& Mason, C. (2007). Standardization versus adaptation: Geographical pressures to deviate from franchise formats. Service Industries Journal, 27(8), 1053-1072.

Dada, L. \& Watson, A. (2012). The effect of entrepreneurial orientation on the franchise relationship. International Small Business Journal, Forthcoming.

Dada, L. \& Watson, A. (2013). Entrepreneurial orientation and the franchise system: Organisational antecedents and performance outcomes. European Journal of Marketing, 47(5/6) (forthcoming).

Darr, E. D., Argote, L. \& Epple, D. (1995). The acquisition, transfer, and depreciation of 
knowledge in service organizations: Productivity in franchises. Management Science , 41(11), 1750-1762.

Davies, M.A.P, Lassar, W., Manolis, C., Prince, M. \& Winsor, R. D. (2011). A model of trust and compliance in franchise relationships. Journal of Business Venturing, 26(3), 321340.

De Clercq, D., Dimov, D. \& Thongpapanl, N. (T.) (2010). The moderating impact of internal social exchange processes on the entrepreneurial orientation-performance relationship. Journal of Business Venturing, 25(1), 87-103.

Delaney, J. T., Lewin, D. \& Ichniowski, C. (1989). Human Resource Policies and Practices in American Firms. Washington, DC: U.S. Government Printing Office.

Delery, J. E. (1998). Issues of fit in strategic human resource management: Implications for research. Human Resource Management Review, 8, 289-309.

Delery, J. E. \& Doty, D. H. (1996). Modes of theorizing in strategic human resource management: Tests of universalistic, contingency and configurational performance predictions. Academy of Management Journal, 39, 802-835.

Elango, B. \& Fried, V. H. (1997). Franchising research: A literature review and synthesis. Journal of Small Business Management, 35, 68-81.

Falbe, C. M., Dandridge, T. C. \& Kumar, A. (1998). The effect of organizational context on entrepreneurial strategies in franchising. Journal of Business Venturing, 14(1), 125140.

Franchise World: British Franchise Directory and Guide. (2009). Franchise World, U.K.

Gassenheimer, J. B., Baucus, D. B. \& Baucus, M. S. (1996). Cooperative arrangements among entrepreneurs: An analysis of opportunism and communication in franchise structures. Journal of Business Research, 36(1), 67-79. 
George, B. A. \& Marino, L. (2011). The epistemology of entrepreneurial orientation: Conceptual formation, modeling, and operationalization. Entrepreneurship Theory and Practice, 35(5), 989-1024.

Gillis, W. E. \& Combs, J. G. (2009). Franchisor strategy and firm performance: Making the most of strategic resource investments. Business Horizons, 52, 553-561.

Gomez-Mejia, L. R. (1992). Structure and process of diversification, compensation strategy, and firm performance. Strategic Management Journal, 13(5), 381-397.

Gomez-Mejia, L. R. \& Balkin, D. B. (1992). Compensation, Organizational Strategy and Firm Performance. Cincinnati, OH: Southwestern Publishing.

Grace, D. \& Weaven, S. (2011). An empirical analysis of franchisee value-in-use, investment risk and relational satisfaction. Journal of Retailing, 87(3), 366-380.

Grünhagen, M., DiPietro, R. B., Stassen, R. E. \& Frazer, L. (2008). The effective delivery of franchisor services: A comparison of U.S. and German support practices for franchisees. Journal of Marketing Channels, 15(4), 315-335.

Grünhagen, M. \& Mittelstaedt, R. A. (2005). Entrepreneurs or investors: Do multi-unit franchisees have different philosophical orientations? Journal of Small Business Management, 43(3), 207-225.

Guest, D. E. (1997). Human resource management and performance: A review and research agenda. International Journal of Human Resource Management, 8(3), 263-276.

Hambrick, D. C., Geletkanycz, M. A. \& Fredrickson, J. W. (1993). Top executive commitment to the status quo: Some tests of its determinants. Strategic Management Journal, 14(6), 401-418.

Hughes M. \& Morgan, R. (2007). Deconstructing the relationship between entrepreneurial 
orientation and business performance at the embryonic stage of firm growth. Industrial Marketing Management, 36(5), 651-661.

Huselid, M. A. (1995). The impact of human resource management practices on turnover, productivity and corporate financial performance. Academy of Management Journal, 38(3), 635-672.

Jambulingam, T. \& Nevin, J. R. (1999). Influence of franchisee selection criteria on outcomes desired by the franchisor. Journal of Business Venturing, 14(4), 363-395.

Kaufmann, P. J. \& Eroglu, S. (1999). Standardization and adaptation in business format franchising. Journal of Business Venturing, 14, 69-85.

Keh, H. T., Nguyen, T. T. M. \& Ng, H. P. (2007). The effects of entrepreneurial orientation and marketing information on the performance of SMEs. Journal of Business Venturing, 22, 592-611.

Ketchen, D. J., Short, J. C. \& Combs, J. G. (2011). Is franchising entrepreneurship? Yes, no, and maybe so. Entrepreneurship Theory and Practice, May, 583-593.

Kreiser, P.M. (2011). Entrepreneurial orientation and organizational learning: The impact of network range and network closure. Entrepreneurship Theory and Practice, 35(5), 1025-1050.

Latham, G. P. (2004). The motivational benefits of goal-setting. Academy of Management Executive, 18(4), 126-129.

Lawrence, B. \& Kaufmann, P. J. (2011). Identity in franchise systems: The role of franchisee associations. Journal of Retailing, 87(3), 285-305.

Lee, C., Lee, K. \& Pennings, J. M. (2001). Internal capabilities, external networks, and performance: a study on technology-based ventures. Strategic Management Journal, 22, 615-640. 
Li, Y., Zhao, Y., Tan, J. \& Liu, Y. (2008). Moderating effects of entrepreneurial orientation on market orientation-performance linkage: Evidence from Chinese small firms. Journal of Small Business Management, 46(1), 113-133.

Lumpkin, G. T. \& Dess, G. (1996). Clarifying the entrepreneurial orientation construct and linking it to performance. Academy of Management Review, 21(1), 135172.

Lumpkin, G. T. \& Dess, G. (2001). Linking two dimensions of entrepreneurial orientation to firm performance: The moderating role of environment and industry life cycle. Journal of Business Venturing, 16, 429-451.

MacDuffie, J. P. (1995). Human resource bundles and manufacturing performance: Organizational logic and flexible production systems in the world auto industry. Industrial and Labor Relations Review, 48(2), 197-221.

McLean, M. (2006). Evaluating the importance and performance of the human resources function: An examination of a medium-sized Scottish retailer. Journal of Retailing and Consumer Services, 13(2), 143-156.

Miller, D. (1983). The correlates of entrepreneurship in three types of firms. Management Science, 29(7), 770-791.

Miller, D. (2006). Strategic human resource management in department stores: An historical perspective. Journal of Retailing and Consumer Services, 13(2), 99-109.

Miller, D. (2011). Miller (1983) revisited: A reflection on EO research and some suggestions for the future. Entrepreneurship Theory and Practice, 35(5), 873-894.

Miller, D. \& Friesen, P. H. (1982b). Strategy-making and environment: The third link. Strategic Management Journal, 4, 221-235.

Moreno, A. M. \& Casillas, J. C. (2008). Entrepreneurial orientation and growth of SMEs: A causal model. Entrepreneurship, Theory and Practice, May, 507-528. 
Morris, M. H., Schindehutte, M. \& LaForge, R. W. (2002). Entrepreneurial marketing: A construct for integrating emerging entrepreneurship and marketing perspectives. Journal of Marketing Theory and Practice, Fall, 1-20.

National Westminster Bank/British Franchise Association Survey. (2008). British Franchise Association, London.

Nunnally, J. C. (1978). Psychometric Theory, $2^{\text {nd }}$ ed. New York: McGraw-Hill.

Pfeffer, J. (1995). Producing sustainable competitive advantage through the effective management of people. Academy of Management Journal, 9, 55-69.

Phillips, L. W. (1981). Assessing measurement error in key informant reports: A methodological note on organizational analysis in marketing. Journal of Marketing Research, 18(4), 395-415.

Podsakoff, P. M., MacKenzie, S. B., Lee, J. \& Podsakoff, N. (2003). Common method biases in behavioural research: A critical review of the literature and recommended remedies. Journal of Applied Psychology, 88, 879-903.

Podsakoff, P. M. \& Organ, D. W. (1986). Self-reports in organizational research: Problems and prospects. Journal of Management, 12(4), 531-544.

Rhee, J., Park, T. \& Lee, D. H. (2009). Drivers of innovativeness and performance for innovative SMEs in South Korea: Mediation of learning orientation. Technovation (forthcoming).

Simsek, Z., Heavey, C., \& Veiga, J. F. (2010). The impact of CEO core self-evaluation on the firm’s entrepreneurial orientation. Strategic Management Journal, 31(1), 110-119.

Simsek, Z., Veiga, J. F. \& Lubatkin, M. H. (2007). The impact of managerial environmental perceptions on corporate entrepreneurship: Towards understanding discretionary slack’s pivotal role. Journal of Management Studies, 44(8), 1398-1424. 
Stanworth, J. (1991). Franchising and the franchise relationship. International Journal of Retail Distribution and Consumer Research, 1(2), 175-199.

Stanworth, J., Healeas, S., Purdy, D., Watson, A. \& Stanworth, C. (2003). Entrepreneurial teams, intellectual capital acquisition and knowledge management - new perspectives on franchising as a small business growth strategy. Proceedings of the International Society of Franchising, San Antonio, Texas.

Tang, J., Tang, Z., Marino, L. D., Zhang, Y. \& Li, Q. (2008). Exploring an inverted U-Shape relationship between entrepreneurial orientation and performance in Chinese ventures. Entrepreneurship, Theory and Practice, January, 219-239.

Tepper, B. J. \& Tepper, K. (1993). The effects of method variance within measures. Journal of Psychology, 127(3), 293-302.

Terry, A. \& DiLernia, C. (2011). Back of house franchising. Proceedings of the International Society of Franchising Conference, Boston, MA.

Wales, W., Monsen, E., \& McKelvie, A. (2011). The organizational pervasiveness of entrepreneurial orientation. Entrepreneurship Theory and Practice, 35(5), 895-923.

Walter, A., Auer, M. \& Ritter, T. (2006). The impact of network capabilities and entrepreneurial orientation on university spin-off performance. Journal of Business Venturing, 21, 541- 567.

Wang, C. L. (2008). Entrepreneurial orientation, learning orientation, and firm performance. Entrepreneurship, Theory and Practice, July, 635-657.

Welsh, D. H. B., Alon, I., \& Falbe, C. M. (2006). An examination of international retail franchising in emerging markets. Journal of Small Business Management, 44(1), 130149.

Wiklund, J., Patzelt, H. \& Shepherd, D. (2009). Building an integrative model of small business growth. Small Business Economics, 32(4), 351-374. 
Wiklund, J. \& Shepherd, D. (2005). Entrepreneurial orientation and small business performance: A configurational approach. Journal of Business Venturing, 20, 71-91. Windsperger, J. (2004). Centralization of franchising networks: Evidence from the Austrian franchise sector. Journal of Business Research, 57(12), 1361-1369.

Youndt, M., Snell, S., Dean, Jr., J. \& Lepak, D. (1996). Human resource management, manufacturing strategy, and firm performance. Academy of Management Journal, 39(4), 836-866.

Zahra, S. A. \& Covin, J. G. (1995). Contextual influences on the corporate entrepreneurship performance relationship: A longitudinal analysis. Journal of Business Venturing, 10, 43-58. 


\section{TABLES}

Table 1: Characteristics of the Sample

\begin{tabular}{|c|c|c|}
\hline Franchise System Characteristics & Frequency & Percentage \\
\hline $\begin{array}{l}\text { Age of franchise system: } \\
\text { Less than } 6 \text { years } \\
\text { 6-10 years } \\
\text { More than } 10 \text { years }\end{array}$ & $\begin{array}{l}29 \\
15 \\
46\end{array}$ & $\begin{array}{l}32 \\
17 \\
51\end{array}$ \\
\hline $\begin{array}{l}\text { Size of franchise system: } \\
1-50 \text { outlets } \\
51-100 \text { outlets } \\
\text { More than } 100 \text { outlets }\end{array}$ & $\begin{array}{l}53 \\
10 \\
25\end{array}$ & $\begin{array}{l}60 \\
11 \\
28\end{array}$ \\
\hline $\begin{array}{l}\text { Industry sector: } \\
\text { Property and maintenance services, home improvements } \\
\text { Catering and Hotels } \\
\text { Cleaning and renovation services } \\
\text { Commercial services } \\
\text { Direct selling, distribution, wholesaling, vending } \\
\text { Domestic, personal, health and fitness, caring, and pet services } \\
\text { Employment agencies, executive search, management } \\
\text { consultancy, training and teaching } \\
\text { Estate agents, business transfer agents, financial services and } \\
\text { mortgage brokers } \\
\text { Parcel and courier services } \\
\text { Printing, copying, graphic design } \\
\text { Retailing } \\
\text { Vehicle services } \\
\text { Other }\end{array}$ & $\begin{array}{r}9 \\
13 \\
7 \\
3 \\
8 \\
4 \\
8 \\
7 \\
\\
1 \\
2 \\
20 \\
9 \\
23\end{array}$ & $\begin{array}{r}8 \\
11 \\
6 \\
3 \\
7 \\
4 \\
7 \\
6 \\
\\
1 \\
2 \\
18 \\
8 \\
20\end{array}$ \\
\hline
\end{tabular}


Table 2: Means, Standard Deviations, and Correlations

\begin{tabular}{|l|l|l|l|l|l|}
\hline Variables & Mean & S.D & $\mathbf{1}$ & $\mathbf{2}$ & $\mathbf{3}$ \\
\hline Performance & 3.626 & 0.624 & 1.000 & & \\
\hline EO & 2.296 & 0.684 & $0.234^{*}$ & 1.000 & \\
\hline HR Autonomy & 3.196 & 1.148 & $-0.223^{*}$ & -0.097 & 1.000 \\
\hline
\end{tabular}

$n=95$

* Correlation is significant at the 0.05 level (2-tailed). 
Table 3: Constructs and Measurement Items

\begin{tabular}{|c|c|c|}
\hline Constructs & Measurement items & $\begin{array}{l}\text { Cronbach's } \\
\alpha \text { values }\end{array}$ \\
\hline Performance & $\begin{array}{l}\text { (1) Profitability }{ }^{\mathrm{a}} \text {. } \\
\text { (2) Sales growth }{ }^{\mathrm{a}} \text {. } \\
\text { (3) Market share }{ }^{\mathrm{a}} \text {. } \\
\text { (4) Overall financial performance }{ }^{\mathrm{a}} \text {. } \\
\text { (5) My system provides secure jobs to franchisees }{ }^{\mathrm{b}} \text {. } \\
\text { (6) My system is realising its franchising goals }{ }^{\mathrm{b}} \text {. } \\
\text { (7) I am satisfied with my franchisees’ overall } \\
\text { performance }{ }^{\mathrm{b}} \text {. }\end{array}$ & 0.82 \\
\hline $\begin{array}{l}\text { Entrepreneurial } \\
\text { Orientation }\end{array}$ & $\begin{array}{l}\text { (1) In my franchise system, there exists a very strong } \\
\text { emphasis on franchisee-driven research and } \\
\text { development, technological leadership, and innovations. } \\
\text { (2) The changes in product lines (e.g., types/number of } \\
\text { products) by my franchisees have usually been dramatic. } \\
\text { (3) My franchisees have introduced many innovations in the } \\
\text { past } 5 \text { years. } \\
\text { (4) My franchisees, by themselves, are typically the first to } \\
\text { initiate actions to competitors, for which the competitors } \\
\text { then respond. } \\
\text { (5) Very often, my franchise outlets are the first to introduce } \\
\text { new products/services, techniques, technologies etc. } \\
\text { (6) My franchisees tend to have a strong preference for high- } \\
\text { risk projects (with chances of very high return). } \\
\text { (7) Owing to the nature of the environment, my franchisees } \\
\text { believe that bold wide-ranging acts are necessary on } \\
\text { their part in order to achieve my franchise system's } \\
\text { objectives. }\end{array}$ & 0.76 \\
\hline $\begin{array}{l}\text { HR Operational } \\
\text { Autonomy }\end{array}$ & $\begin{array}{l}\text { (1) Franchisees are free to establish their own standards for } \\
\text { employee evaluation. } \\
\text { (2) Franchisees determine their own safety and security } \\
\text { policies. } \\
\text { (3) Franchisees can decide how often they perform } \\
\text { employee performance appraisals. } \\
\text { (4) Franchisees set their own internal compensation and pay } \\
\text { standards. } \\
\text { (5) Franchisees have control over negotiations and } \\
\text { relationships with unions. }\end{array}$ & 0.83 \\
\hline
\end{tabular}

${ }^{\mathrm{a}}$ Measured relative to those of competitors in the last 3 years.

${ }^{\mathrm{b}}$ Measured with regards to the last 3 years. 
Table 4: Regression Results

\begin{tabular}{|c|c|c|}
\hline Variable & $\begin{array}{l}\text { Model 1 } \\
\text { (Base Model) } \\
\beta\end{array}$ & $\begin{array}{l}\text { Model } 2 \\
\text { (Hypothesis) } \\
\beta \\
\end{array}$ \\
\hline \multicolumn{3}{|l|}{ Controls: } \\
\hline $\begin{array}{l}\text { Size of franchise system } \\
\text { Age of franchise system }\end{array}$ & $\begin{array}{l}0.064 \\
0.262 * * \\
\end{array}$ & $\begin{array}{l}0.154 \\
0.187 * * * \\
\end{array}$ \\
\hline $\mathrm{EO}$ & $0.275 * *$ & $0.207 * *$ \\
\hline HR AUTONOMY & & -0.162 \\
\hline H: EO*HR AUTONOMY & & $0.220 * *$ \\
\hline $\begin{array}{l}\mathrm{F} \text { value } \\
\mathrm{R}^{2} \\
\Delta \mathrm{R}^{2}\end{array}$ & $\begin{array}{l}5.204^{*} \\
0.165\end{array}$ & $\begin{array}{l}4.858^{*} \\
0.229 \\
0.064^{*}\end{array}$ \\
\hline
\end{tabular}

Standardized coefficients are displayed in the table

${ }^{*} \mathrm{p}<0.01$

$* * \mathrm{p}<0.05$

$* * * \mathrm{p}<0.10$ 